Демешок О. О.

канд. економ. наук, дочент

ДУ «Інститут економіки природокористування та сталого розвитку НАН України»

\title{
ІННОВАЦІЙНО-ІНВЕСТИЦІЙНІ ДЕТЕРМННАНТИ УПРАВЛІННЯ РОЗВИТКОМ СТРАТЕГІЧНОГО ПОТЕНЦІАЛУ ПРОМИСЛОВОСТІ
}

\author{
ИННОВАЦИОННО-ИНВЕСТИЦИОННЫЕ ДЕТЕРМИНАНТЫ УПРАВЛЕНИЯ \\ РАЗВИТИЕМ СТРАТЕГИЧЕСКОГО ПОТЕНЦИАЛА ПРОМЫШЛЕННОСТИ
}

\section{INNOVATION AND INVESTMENT DETERMINANTS OF DEVELOPMENT MAN- AGEMENT STRATEGIC POTENTIAL OF INDUSTRY}

Автором підтверджено нагальну необхідність щзодо визначення та формалізаиії міри залежності базових макроекономічних показників, у тому числі: між інвестиційною активністю промисловості та обсягами випуску інноваційної продукиії із загальним випуском промислової продукиї та обсягами ВДВ промисловості Украӥни. Вказане обчислено за урахування кількості впроваджених прогресивних технологічних прочесів, обсягами капітальних інвестицій в ОВЗ та загальних інноваційних витрат протягом ретроспективного періоду. Зазначене встановлено за використання дистрибутивно-лагових моделей зміманого типу з ідентифікацією трансформаційних змін. Визначено доиільність формалізації лагових термінів у п'ять років, щзо дозволило: а) здійснити об'єктивізацію оцінок та встановити вагомість впливу структурно-динамічних змін, які відбуваються в межах окремих показників, на трансформацію базових параметрів розвитку промисловості Украӥни та темпи нарощення ї̈ стратегічного потенціалу; б) порівняти кількісні значення індексів інфлямії в Украӥні та иін виробників промислової продукиії у 2015 р.; в) визначити динамічність їхніх змін у першій половині 2015 р. та обгрунтувати імовірність раціоналізації освоєння стратегічного потенщіалу.

Ключові слова: сталий розвиток, стратегічний потенціал, прогноз.

Подтверждена необходимость определения и формализации зависимости базовых макроэкономических показателей, в том числе: между инвестиционной активностью промышленности и объемами выпуска инновационной продукиии с выпуском промышленной продукции и объемами ВДС промышленности Украины. Это рассчитано с учетом количества внедренных прогрессивных технологических прочессов, объемов капитальных инвестиций в основные промышленные фонды и общих инновационных расходов в ретроспективном периоде. Это определено за результатами формирования дистрибутивнолаговых моделей смешанного типа при идентификации трансформационных изменений. Обоснована целесообразность формализации пятигодичного лага, что позволило: а) осуществить объективизацию оценок и установить значимость структурно-динамических изменений на трансформачию базовых параметров развития промышленности Украины и темпы наращивание ее стратегического потенциала; б) сравнить количественные значения индексов инфляции в Украине и цеен на промышленную продукцию в 2015 году; в) определить динамичность их изменений в первой половине 2015 года и обосновать возможность рационализации освоения стратегического потенцииала. 
Ключевые слова: устойчивое развитие, стратегический потенциал, прогноз.

The confirmed the need for defining and formalizing depending macroeconomic fundamentals, including investment activity between industry and the production volumes innovation of products with the release of industrial output and the volume of Airborne Industry of Ukraine. It is calculated based on the amount of the introduction of advanced technological processes, the volume of capital investments and general industrial innovation expenditure retrospective period. This is determined by the results of the formation of the distribution-but-lagged models of mixed type in the identification of transformational change. Determined formalization lag of five years, which allowed: a) to carry out assessments of objectification and tired-twist the importance of structural and dynamic changes in the transformation parameters of development of Ukrainian industry and the pace of its strategic potential; b) to compare the quantitative indexes of inflation in Ukraine and the prices of industrial products in 2015; c) defined-casting dynamics of their changes in the first half of 2015 and justify the possibility of rationalizing the development of strategic potential.

Keywords: sustainable development, strategic potential, prognosis.

Вступ. Ключовим фактором убезпечення переходу до сталого розвитку будь-якої держави світу та ії регіонів - є вирішення нагальних проблем у площині забезпечення результативності управління розвитком стратегічного потенціалу промисловості та формування адекватного конкурентного середовища. Зазначене, у свою чергу, потребує розробки та реалізації комплексу дієвих заходів, спрямованих на (визнано автором у попередній роботі [1]): а) досягнення об'єктивності та адекватності використовуваного методичного і прикладного інструментарію; б) стимулювання кардинальної модернізації основних виробничих засобів (ОВ3) і не лише у паливно-енергетичному комплексі, а й у базових видах економічної діяльності; в) активізація впровадження енергозберігаючих технологій, енергетичного обліку та енергоаудиту; г) розробка і використання цільового програмного забезпечення і прогресивних еко- безпечних промислових технологій; д) галузеву, територіальну, технологічну та комунікаційну реструктуризацію реального сектору. Поряд із цим, необхідно стимулювати процеси модернізації транспортних мереж та суттєве зменшення втрат різних видів ресурсів при їхньому транспортуванні та розподіленні (i, відповідно, при генеруванні) задля цілеорієнтованого формування та раціоналізації використання стратегічного потенціалу промисловості.

Постановка завдання. У відповідності з зазначеним вище, досягти забезпечення результативності управління розвитком стратегічного потенціалу промисловості України можна лише за наслідками запровадження дієвої системи управління та сформування ефективної інноваційно-інвестиційної політики при захисті добросовісної конкуренції у підприємницькій діяльності, що $\epsilon$ одним із пріоритетних напрямів реалізації державної промислової стратегії.

Методологія дослідження. У ході дослідження задля вирішення науково-прикладного завдання та об'єктивізації оцінок синхронно використано: а) 
принципи системно-комплексного, об'єктно-цільового, процесного і синергетичного підходів; б) методи: економетричні; економіко-статистичні; прийоми групування; схематичного та графічного зображення даних; кластерного аналізу, моделювання, індикативного оцінювання та матричний підхід до обгрунтування пріоритетів.

Результати дослідження. Зазначимо, що на впровадження у практику господарювання прогресивних інновацій у 2014 р. [2 - 4] промислові підприємства витратили (у фактичних цінах) менше, ніж у 2013 р. (2013 p. - 9,56 млрд. грн.) - а, саме, 7,70 млрд. грн. У тому числі (табл. 1) на: а) придбання машин, обладнання та програмного забезпечення - 5,1 млрд. грн. $(66,5 \%$ від загального обсягу інноваційних витрат); б) провадження внутрішніх та зовнішніх науково-дослідних розробок - 1,7 млрд. грн. (22,8\%); в) придбання інших зовнішніх знань (придбання нових технологій) $-47,20$ млн. грн. $(0,6 \%) ;$ г) інші інноваційні витрати становили лише - 0,8 млрд. грн. $(10,1 \%)$.

Як відомо [2 - 4], основним джерелом фінансування інноваційних витрат 2012 - 2014 рр. залишаються власні кошти підприємств (у 2014 р. - становило 70,8 \%). При цьому, обсяг фінансових витрат: а) державного бюджету України та місцевих бюджетів становив на рівні 349,8 млн. грн. (або 0,39 \%); б) вітчизняних та іноземних інвесторів дорівнював - 146,9 млн. грн. (або 0,19 $\%$ ); в) отриманих за різними кредитами, становив - 561,1 млн. грн. (або 6,5 \%). Проте, враховуючи динаміку змін індексів цін виробників промислової продукції та інфляції в Україні (репрезентовано на рис. 1), можна отримати об'єктивну оцінку обсягів інноваційних витрат та вимірів раціональності їхнього використання у $2008-2014$ pp. за урахування порівняльних цін 2014 року. Зазначене дозволяє визнати наступне: протягом 2008 - 2014 pp. відбувалось зниження обсягів інноваційних витрат, що обумовило, відповідно, і зменшення частки інноваційної продукції у загальному обсязі реалізованої промислової продукції в Україні (із 5,9\% у 2008 р. до 2,5\% - у 2014 р.).

Перерахунок інноваційних витрат за порівняльними цінами (див., табл. 1) дозволяє підтвердити про те, що виняткове падіння відбулося саме у площині реалізації процесів із інформатизації промислового виробництва та придбання програмного забезпечення. Зазначене унеможливило, у достатній мірі, забезпечити результативність функціонування реального сектору економіки України та системи управління розвитком стратегічного потенціалу, зокрема.

Поряд із зазначеним, слід признати і про те, що за ретроспективний період (2008 - 2014 pp.), практично, не відбувалось управління технічної підготовки виробництва до впровадження інновацій при скороченні інших видів інноваційних витрат. 
Таблиця 1

Наслідки провадження інноваційно-інвестиційної діяльності у промисловості України у 2008 - 2014 рр.*

\begin{tabular}{|c|c|c|c|c|c|c|c|c|c|c|c|c|c|c|c|}
\hline \multirow{3}{*}{$\begin{array}{c}\text { Ретро- } \\
\text { спек- } \\
\text { тивний } \\
\text { період, } \\
\text { роки }\end{array}$} & \multirow{2}{*}{\multicolumn{3}{|c|}{$\begin{array}{c}\text { Питома вага підпри- } \\
\text { смств, що }\end{array}$}} & \multicolumn{7}{|c|}{$\begin{array}{c}\text { Витрати на інноваційну діяльність, у т. ч. за напрямами і } \\
\text { окремими джерелами фінансування, млрд. грн. }\end{array}$} & \multirow{2}{*}{\multicolumn{2}{|c|}{$\begin{array}{c}\text { Впроваджено те- } \\
\text { хнологічних } \\
\text { процесів, кіл-сть }\end{array}$}} & \multirow{2}{*}{\multicolumn{2}{|c|}{\begin{tabular}{|c} 
Освосно ви- \\
робництво \\
інновацій- \\
них видів \\
продукцї̈, \\
наймень
\end{tabular}}} & \multirow{3}{*}{\begin{tabular}{|c|} 
Питома \\
вага реа- \\
лізованої \\
інновац. \\
продукції \\
до зага- \\
льного \\
обсягу \\
пром.-ої \\
продук- \\
ції, \%
\end{tabular}} \\
\hline & & & & \multicolumn{5}{|c|}{ напрями } & \multicolumn{2}{|c|}{ джерела } & & & & & \\
\hline & \multicolumn{2}{|c|}{$\begin{array}{c}\text { впроваджу- } \\
\text { вали інно- } \\
\text { вації, \% }\end{array}$} & $\left|\begin{array}{c}\text { займалися } \\
\text { інновацій- } \\
\text { ною діяль- } \\
\text { ністю, \% }\end{array}\right|$ & усього & $\begin{array}{c}\text { дослі- } \\
\text { дження } \\
\text { i розро- } \\
\text { бки }\end{array}$ & $\begin{array}{c}\text { прид- } \\
\text { бання } \\
\text { ін. зов- } \\
\text { нішніх } \\
\text { знань }\end{array}$ & \begin{tabular}{|c|} 
придбання \\
обладнання \\
i про- \\
грамного \\
забезпе- \\
чення \\
\end{tabular} & \begin{tabular}{|} 
підготовка \\
вир-ва до \\
нова-цій та \\
ін. інно- \\
вац. ви- \\
трати
\end{tabular} & $\begin{array}{c}\text { частка } \\
\text { власних } \\
\text { коштів, } \\
\%\end{array}$ & $\begin{array}{c}\text { частка } \\
\text { бюджет- } \\
\text { ного фі- } \\
\text { нансу- } \\
\text { вання, \% }\end{array}$ & Усього & $\begin{array}{l}\text { у т.ч. ма- } \\
\text { ловідход- } \\
\text { ні, ресур- } \\
\text { созбері- } \\
\text { гаючі }\end{array}$ & $\begin{array}{c}\text { Усьо } \\
\text { го }\end{array}$ & $\begin{array}{c}3 \text { них } \\
\text { нові } \\
\text { види } \\
\text { тех- } \\
\text { ніки }\end{array}$ & \\
\hline 1 & & 2 & 3 & 4 & 5 & 6 & 7 & 8 & 9 & 10 & 11 & 12 & 13 & 14 & 15 \\
\hline \multicolumn{16}{|c|}{ Фактичні ичіни } \\
\hline 2008 & 1 & 10,80 & 13,00 & 12,00 & 1,24 & 0,40 & 7,70 & 2,66 & 72,60 & 3,30 & 1647 & 680 & 2446 & 758 & 5,90 \\
\hline 2009 & 2 & 10,70 & 12,80 & 8,00 & 0,84 & 0,10 & 5,00 & 2,06 & 51,60 & 1,20 & 1893 & 753 & 2685 & 641 & 4,80 \\
\hline 2010 & 3 & 11,50 & 13,80 & 8,10 & 1,00 & 0,10 & 5,10 & 1,90 & 47,70 & 0,80 & 2043 & 479 & 2408 & 663 & 3,80 \\
\hline 2011 & 4 & 12,80 & 16,20 & 14,30 & 1,07 & 0,30 & 10,50 & 2,43 & 75,80 & 1,00 & 2510 & 517 & 3238 & 897 & 3,80 \\
\hline 2012 & 5 & 13,60 & 17,40 & 11,50 & 1,19 & 0,04 & 8,10 & 2,17 & 73,30 & 2,00 & 2188 & 554 & 3403 & 942 & 3,30 \\
\hline 2013 & 6 & 13,60 & 16,80 & 9,56 & 1,63 & 0,08 & 5,50 & 2,35 & 69,70 & 0,20 & 1576 & 502 & 3138 & 809 & 3,30 \\
\hline 2014 & 7 & 12,10 & 16,10 & 7,70 & 1,70 & 0,05 & 5,10 & 0,80 & 70,80 & 0,39 & 1743 & 447 & 3661 & 1314 & 2,50 \\
\hline \multicolumn{16}{|c|}{ Порівняльні иіни 2013 року } \\
\hline 2008 & 8 & 0,80 & 13,00 & 22,28 & 2,30 & 0,76 & 14,29 & 4,93 & 72,60 & 3,30 & 1647 & 680 & 2446 & 758 & 5,90 \\
\hline 2009 & 9 & 10,70 & 12,80 & 14,59 & 1,53 & 0,19 & 9,12 & 3,76 & 51,60 & 1,20 & 1893 & 753 & 2685 & 641 & 4,80 \\
\hline 2010 & 10 & 11,50 & 13,80 & 12,44 & 1,54 & 0,15 & 7,83 & 2,92 & 47,70 & 0,80 & 2043 & 479 & 2408 & 663 & 3,80 \\
\hline 2011 & 11 & 12,80 & 16,20 & 19,24 & 1,44 & 0,41 & 14,13 & 3,26 & 75,80 & 1,00 & 2510 & 517 & 3238 & 897 & 3,80 \\
\hline 2012 & 12 & 13,60 & 17,40 & 15,41 & 1,59 & 0,05 & 10,85 & 2,92 & 73,30 & 2,00 & 2188 & 554 & 3403 & 942 & 3,30 \\
\hline 2013 & 13 & 13,60 & 16,80 & 9,56 & 1,63 & 0,08 & 5,50 & 2,35 & 69,70 & 0,20 & 1576 & 502 & 3138 & 809 & 3,30 \\
\hline 2014 & 14 & 12,10 & 16,10 & 6,24 & 1,38 & 0,04 & 4,13 & 0,69 & 70,80 & 0,39 & 1743 & 447 & 3661 & 1314 & 2,50 \\
\hline
\end{tabular}

Джерело * Обчислено, узагальнено та систематизовано автором даного дослідження за даними, приведеними у джерелах [4; 5] 


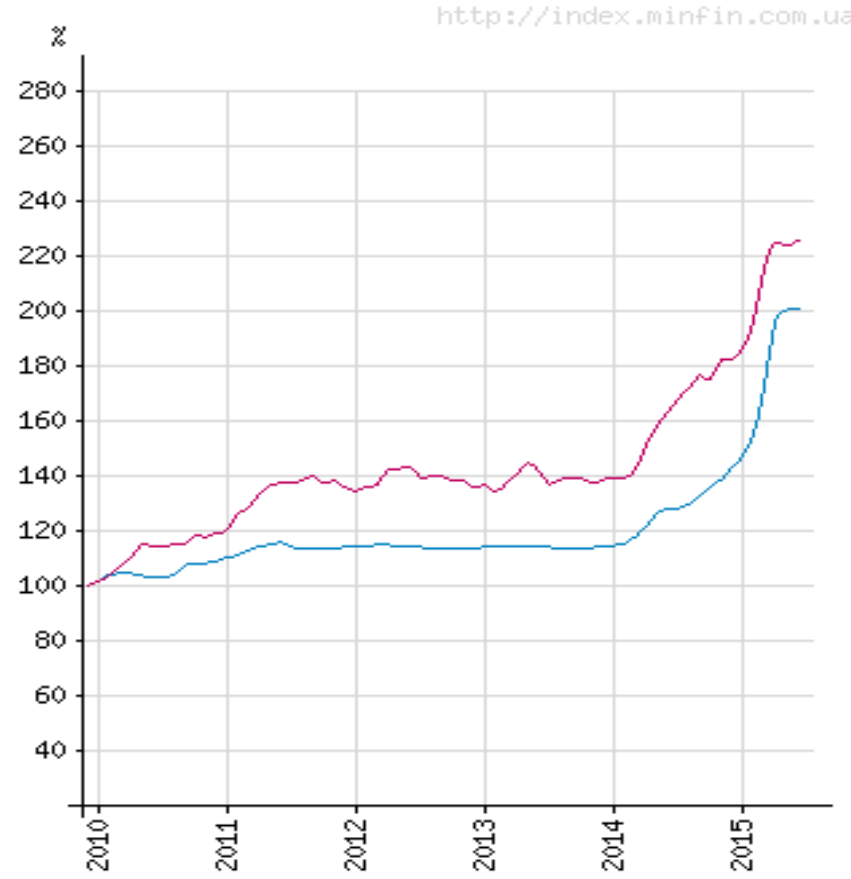

Рис. 1. Динаміка індексів цін виробників промислової продукції та інфляції в Україні у 2010 - 2015 рр. (візуалізовано за даними [2])

Відтак, здійснюючи, відповідно, порівняльну оцінку кількісних значень індексів інфляції (індекс споживчих цін - ІСЦ) в Україні та цін виробників промислової продукції у 2015 р. (з ідентифікацією динамічності їхніх змін у першій половині 2015 р. - табл. 2), слід признати об'єктивним наступне:

a) споживча інфляція в Україні у січні - квітні 2015 р. прискорилася та суттєво перевищила очікування. Так, зокрема, ІСЦ із січня до квітня 2015 р. збільшився на 37,1\% (див., табл. 2), а до відповідного періоду минулого року вже на 42,7\%. Найбільше прискорення припало на березень та квітень 2015 р. Це було пов'язано з піковою девальвацією гривні наприкінці лютого та виникненням iї вторинних ефектів і, відповідно, обумовило підвищення тарифів у сфері житлово-комунального господарства. Зазначене обумовлено, у тому числі і методологічними особливостями відображення реальних цін на природний газ у ІСЦ - тому, у квітні 2015 р. споживча інфляція перевищила 60,0\% у річному вимірі (однак, у травні сповільнилася до 58,4\%). Тому, вважаємо, що імовірний індекс інфляції на кінець 2015 р. становитиме на рівні не нижчому ніж $141,1^{1}$. Звідси, припустимим є таке: на кінець 2015 р., на твердження і передбачення автора, є значення, що перевищить розрахункове и становитиме більш ніж 145,9;

\footnotetext{
${ }^{1}$ Зазначимо, що за запланованими на поточний рік обгрунтуваннями (суб'єктами державного управління), ІСЦ визначено на рівні 139,3.
} 
б) зростання індексу цін виробників промислової продукції в Україні, досягнувши у березні 2015 р. рекордного з початку 1996 р. рівня $(51,7 \%)$, сповільнилося до 42,0\% у травні у річному вимірі.

Таблиця 2

Порівняння індексів споживчих цін та цін виробників промислової продукції в Україні у поточному періоді (2015 р.) *

\begin{tabular}{|c|c|c|c|c|c|}
\hline \multirow{2}{*}{$\begin{array}{c}\begin{array}{c}\text { Поточний період } \\
\mathbf{2 0 1 5} \text { p. }\end{array} \\
1\end{array}$} & \multicolumn{2}{|c|}{$\begin{array}{c}\text { Індекс споживчих цін (ін- } \\
\text { декс інфляції) }\end{array}$} & \multicolumn{2}{|c|}{$\begin{array}{c}\text { Індекс цін виробників про- } \\
\text { мислової продукції }\end{array}$} & \multirow{2}{*}{$\begin{array}{c}\text { Різниця } \\
6\end{array}$} \\
\hline & 2 & 3 & 4 & 5 & \\
\hline січень & 103,1 & 3,10 & 102,3 & 2,30 & 0,8 \\
\hline лютий & 105,3 & 8,60 & 104,8 & 7,20 & 1,4 \\
\hline березень & 110,8 & 20,30 & 110,5 & 18,50 & 1,8 \\
\hline квітень & 114,0 & 37,10 & 104,0 & 23,20 & 13,9 \\
\hline травень & 102,2 & 40,10 & 99,6 & 22,70 & 17,4 \\
\hline червень & 100,4 & 40,70 & 100,6 & 23,40 & 17,3 \\
\hline липень & 101,3 & 41,10 & 101,6 & 23,60 & 17,5 \\
\hline $\begin{array}{c}\text { серпень - } \\
\text { вересень }\end{array}$ & 105,2 & & 102,5 & & \\
\hline $\begin{array}{r}\text { жовтень - } \\
\text { листопад }\end{array}$ & 107,3 & & 104,9 & & \\
\hline грудень & 109,0 & & 105,9 & & \\
\hline за 2015 рік & 14 & 45,9 & & 137,7 & \\
\hline
\end{tabular}

Джерело * Обчислено та узагальнено автором даного дослідження за даними, приведеними у джерелах $[2 ; 5 ; 6]$.

Однак, вважаємо, що індекс цін виробників промислової продукції, скоріше всього, перевищить заплановане значення - i становитиме на кінець 2015 p. - вже понад 131,7.

Відтак, необхідно визнати, що прикметною ознакою сучасного історичного етапу розвитку реального сектору економіки України та національного господарства, у цілому - $є$ господарювання промислових підприємств, усіх без винятку галузей та виробництв, як відкритих незбалансованих систем. Оскільки, функціонують вони в умовах ресурсних обмежень у нестійкому зовнішньому економічному середовищі при мінімальних витратах на реструктуризацію та інноваційно-інформаційну трансформацію основних виробничих засобів (ОВ3) суб'єктів господарювання в межах промисловості держави.

Підкреслимо, що різно-векторні інтеграційні процеси, які мають місце в державі, сформували передумови щодо виникнення й нарощення соціальноекономічних та суспільно-політичних загроз і негативних змін у економіці України. Звідси, за економіко статистичними свідченнями, узагальненими та репрезентованими автором (див., табл. 1) розрахунками, можна формалізувати кореляційну матрицю, побудовану між базовими значеннями макроекономічних параметрів. Тобто, наступних вимірів - макроекономічних показників: а) випуск промислової продукції; б) кількість впроваджених нових технологіч- 
них процесів; в) обсяг ВДВ по промисловості, у цілому; г) обсяг капітальних інвестицій у ОВ3; д) обсяг інноваційних витрат. Їхня формалізація здійснена із лагом у п'ять років задля об'єктивізації оцінок вагомості впливу структурно-динамічних змін, які відбулися за окремими ретроспективними показниками, на трансформацію базових параметрів розвитку промисловості України.

3 огляду на приведені данні, найбільші коефіцієнти кореляції існують між основними макроекономічними показниками промисловості та кількістю впроваджених технологічних процесів і капітальними інвестиціями в ОВЗ. Ці відносні значення знаходяться в межах від 0,80 до 0,87 . Однак, в ситуації, яка має, наразі, у площині освоєння інноваційних витрат, то кореляційна залежність $є$ суттєвою (за обгрунтуваннями положень економетрики - суттєвою $\epsilon$ залежність, яка $є$ вищою, ніж 0,51), проте, відносно, не великою - на рівні 0,51. Але, зауважимо, що продовжуючи економіко-статистичний аналіз засвідчимо, що інноваційні витрати мають надзвичайній вплив на обсяги випуску продукції $(0,93)$ і ВДВ $(0,93)$, проте, не на рівень капітальних інвестицій (за 2008 - 2014 рр.). Звідси, за 2005 - 2010 рр.: обсяг ВДВ до капітальних інвестицій становив 0,98, а у 2006 - 2011 рр. - 0,81. I, відповідно, у 2007 - 2012 рр. та $2008-2013$ pp. $-0,81$ та 0,84 .

Таким чином, можна зробити висновок і про існування суттєвої залежності між інноваційними витратами та обсягами ВДВ промисловості (з відставанням 4-6 років) у 2005 - 2010 рр.; 2006 - 2011 рр.; 2007 - 2012 рр.; 2008 2013 pp. - що складають, відповідно: 0,93; 0,69; 0,75; 0,51. Відтак, вихідною умовою задля розрахунку короткострокового прогнозу окремих/ базових макроекономічних показників промисловості, що визначують умови формування ii стратегічного потенціалу є припущення щодо об'єктивної імовірності:

а) стабілізації загальноекономічної динаміку у промисловості та можливості, щодо елемінування суспільно-політичних загроз функціонуванню національній економічній системі на етапі її розвитку;

б) поступової регенерації промислового потенціалу держави i відновлення виробничо-економічних звязків на всій території із убезпеченням тісної взаємодії / співпраці з міжнародними фінансовими та інвестиційними фондами.

Отже, відмітимо що за основними макроекономічними показниками (станом на початок 2015p.) очікуваним є паритет, або, навіть, незначне падіння за більшістю макроекономічних показників в межах реального сектору. Так, зокрема, випуск продукції промисловості України очікує суттєвий спад на 5,7 млрд грн. ( або на 0,5 \% - репрезентовано на рис. 2), а за значенням обсягів ВДВ по промисловості - імовірна стабілізація - однак, отримані відхилення можна ідентифікувати лише за насліками зростання цін 
виробників промислової продукції (i, відповідно, лише на 0,1 \% - вказане наведене автором на рис. 3).

Проте, більш розгорнутий і грунтований аналіз отриманих тененцій дозволяє їх визнати в якості неявних або непредбачуваних трансформацій основних макроекономічних показників при поступовій схильності до істотного спаду.

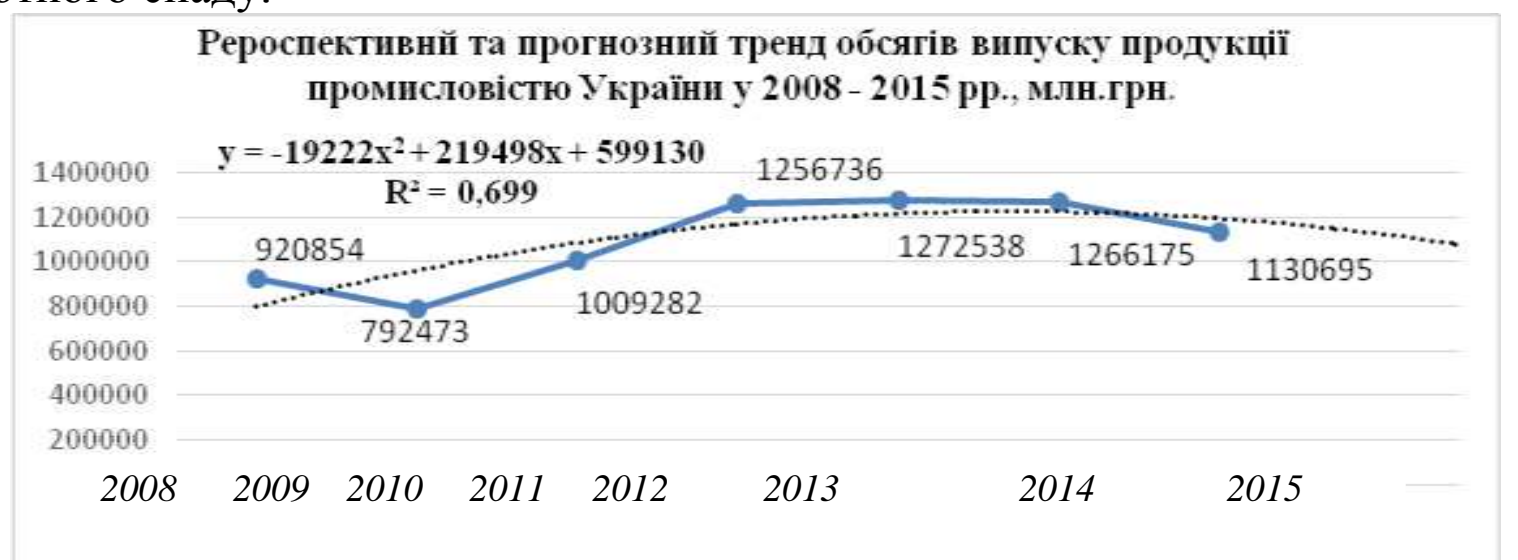

Рис. 2. Дослідно-експериментальна оцінка ретроспективних та прогнозноаналітичних значень обсягів випуску промислової продукції в Україні у ретроспективному періоді (2008 - 2015 рр.) (побудовано автором за даними $[2 ; 7]$

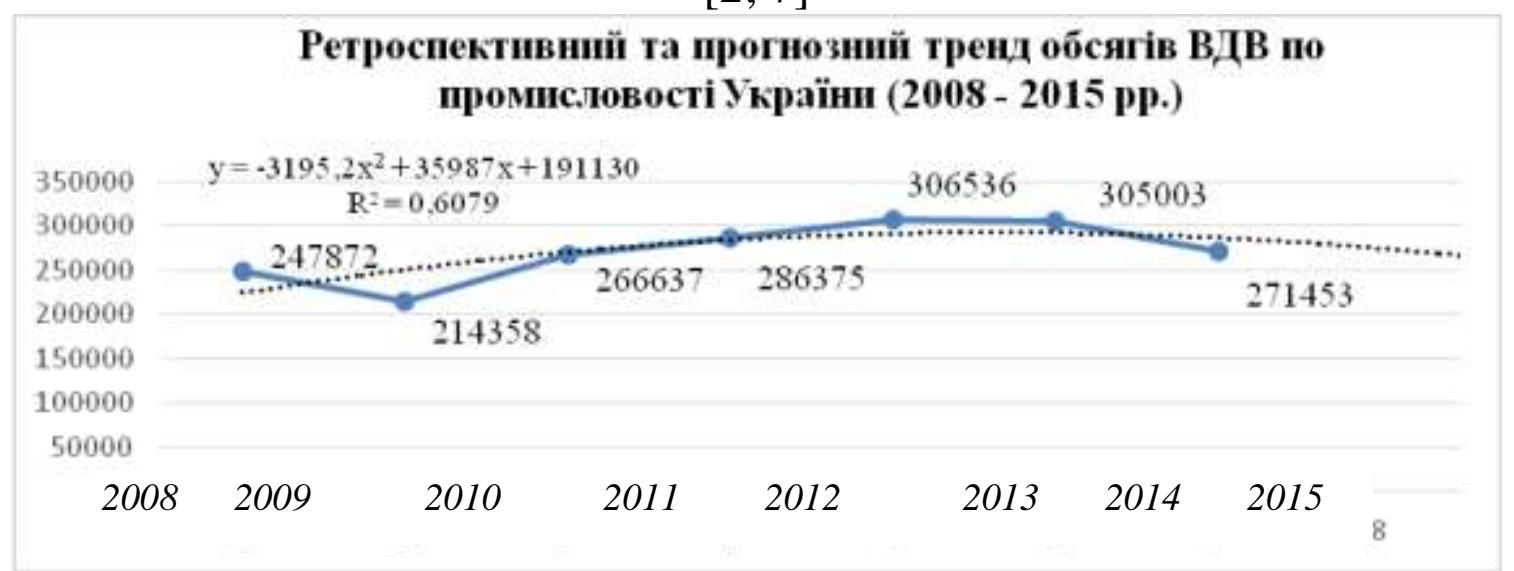

Рис. 3. Дослідно-експериментальна оцінка ретроспективних та короткострокових прогнозно-аналітичних значень обсягів ВДВ у промисловості України у ретроспективному періоді (2008 - 2015 pp.) (побудовано автором за даними $[2 ; 6]$

Поряд із цим, імовірним (на кінець 2015 р.) $є$ падіння обсягів капітальних інвестицій (з 223,7 до 176,3 млрд. грн.), або на 45,0\% (це у порівнянні зі значеннями 2013 р.). Інноваційні витрати також обумовлють суттєві зміни - прогнозоване падіння на $16,0 \%$.

3 огляду на зазанчене вище свідчення, які візуалізовано автором на рис. 2 - можна визнати про те, що представлені вище автором досліження параметри та імовірні структурно-динамічні зрушення основних 
макроекономічних показників - $\epsilon$, у більшій мірі, об'єктивними і відповідають сучасним умовам функціонування реального сектору України. Поряд із цим, падіння індексу промислової продукції в Україні обумовлено також і суттєвим кількісним зниженням значенням останнього в межах окремих регіонів, що $\mathrm{i}$ може ініціювати зменшення масштабів розвиненості стратегічного потенціалу промисловості, у цілому.

Певним чином підсумовуючи результати економіко-статистичного аналізу, засвідчимо про таке: побудований короткостроковий прогноз (на кінець 2015 р. - початок 2016 р.) свідчить про порівняно високу чутливість реального сектору до змін у зовнішньому середовищі функціонування. На противагу їм, ще вищу чутливість до суспільно-політичних та соціально-економічних трансформацій демонструють провідні фундаментальні показники.

Підтвердимо наступне: враховану динаміку та об'єктивні закономірності останніх, вважаємо, можна використати в якості результуючої ознаки обгрунтування комплексу заходів по ціле орієнтованому розвитку стратегічного потенціалу промисловості задля генерування системних умов у площині усунення загроз економічній безпеки держави до 2020 р. (тобто, у найближчі 4-6 років).

Поряд із зазначеними вище обгрунтуваннями та економікостатистичними викладками, враховуючи загальноекономічну динаміку останніх років щодо обсягів та структури прямих іноземних інвестицій в ОВ3 промисловості, а також їхнього розподілу за регіонами держави, можна засвідчити: існують реальні передумови щодо нарощення обсягів експорту промислової продукції, хоча, зовнішньоекономічний потенціал реального сектору держави ще має, доволі, не великий масштаб, з огляду на те, що коефіцієнт покриття експорту промислової продукції імпортом - не перевищував у ретроспективному періоді 3,0\%.

Звідси, підтвердимо: формування відповідних організаційноекономічних засад / умов щодо нарощення масштабів експорту промислової продукції та раціоналізації інвестиційної діяльності в межах реального сектору економіки уможливить оптимізацію структурних зрушень, однак, за рахунок розвитку конкурентного середовища.

Як видно зі свідчень, приведених і обгрунтованих у аналітичних джерелах [8], сприйнятливість промисловості України до зростання впливу іноземної конкуренції відбувалось протягом 2008 - 2014 рр. не рівномірно. Зазначене потребує, деталізації ретроспективних тенденцій та визначення існуючих закономірностей у контексті обгрунтування конститутивно-ключового комплексу проблем і перешкод на шляху формування, нарощення та раціоналізації використання стратегічного потенціалу реального сектору України.

Таким чином, можна підтвердити е, що суб'єктам державного управління, які опікуються проблемами формування стратегічного потенціалу промисловості, слід локалізувати суттєві зусилля щодо усунення порушень чинного 
законодавства про захист економічної конкуренції. Також, слід сприяти органам влади, місцевого самоврядування та адміністративно-організаційного управління і контролю по запобіганню вчинення неправомірних дій, що можуть мати негативний вплив на конкуренцію на внутрішньому ринку.

У цьому контексті вважаємо за необхідне признати і підтвердити, що корелянтам різного рівня управління необхідно зважати і враховувати у своїй діяльності усталені положення інституційної теорії Дугласа Норта [9] та сучасної інституціональної теорії, які засвідчують та підтверджують наступне:

саме від якості та здатностей державних інституцій залежить технологічний розвиток не лише промисловості, а й життєздатність країни та національна безпека, у цілому. Однак, сучасна система державного управління, на це час: а) проводить деструктивну практику та спрямовує діяльність лише на організаційне реформування державних інституцій, які опікуються проблемами формування стратегічного потенціалу промисловості; б0 формує «лозунгову політику» реструктуризації промисловості. При цьому, суб'єкти державного управління не займаються провадженням (у т.ч. і розробкою та добором) комплексу прогресивних і дієвих заходів задля: генеруванням системних ознак в межах національної економічної системи у контексті кардинальної технологічної регенерації економіки України; відродження стратегічного потенціалу та модернізації реального сектору. Оскільки, політична еліта, на цей час, зайнята та переймається лише силовим коригуванням державної економічної політики і провадженням змін у: а) вихідні положення Конституції України; б) процедури реалізації місцевих виборів; в) внутрішньо коаліційній боротьбі та, так називаному, елімінуванню «корупційних схем» тощо.

Висновки. Таким чином, щодо висновків, отриманих автором за результатами економіко-статистичного дослідження інноваційно-інвестиційних детермінант управління розвитком стратегічного потенціалу промисловості, які стосуються сучасних умов іï функціонування та раціоналізації освоєння останнього, то можна признати таке:

у наслідок нагромадження різних за природою загроз економічної, фінансової та суспільно-політичної кризи (у 2013 - 2015 рр.), які мають місце, наразі, в державі, виникають/ згенеровано суттєві обмеження щодо нарощення масштабів інноваційного потенціалу та пошуку і використання вільних інвестиційних коштів, які могли б бути спрямованими на термінове введення технологічних новацій, активізацію науково-дослідних розробок. Тому, вважаємо, що, наразі, $\epsilon$ нагальна потреба у розробленні та реалізації у практиці господарювання оптимальної для України політики управління розвитком стратегічного потенціалу промисловості, що базується на стратегічному інструментарії: раціоналізації інноваційно-інвестиційних відносин; технології управління процесного типу; забезпечення національних економічних інтересів та 
підвищення рівня економічної безпеки (доведено автором у попередній роботі [7]).

Підсумовуючи результати економіко-статистичних оцінок та моделювання базових макроекономічних показників, слід признати наступне: автором було обрано для аналізу три базові виміри, які відтворюють вихідні параметри інноваційної здатності української промисловості, враховують ії інвестиційне забезпечення, міру вагомості їхнього впливу на обсяги випуску промислової продукції та ВДВ і, відтак, на темпи формування й освоєння стратегічного потенціалу. У відповідності з цим, засвідчимо: а) впровадження нових технологічних процесів та нарощення обсягів капітальних інвестиції у OB3 реального сектору, безпосередньо, і суттєво впливають на економічну складову, яка уможливлює збалансоване функціонування промисловості України; б) інноваційні витрати та визначеність об'єктів їх докладання, значення яких проаналізовано з лагом у 4-6 років (у порівняльних цінах 2014 р.), обумовлюють зрушення у масштабах розвиненості стратегічного потенціалу реального сектору економіки України.

\section{Література:}

1. Демешок О. О. Сталий розвиток держави: синхронність процесів макроекономічного регулювання та макросистемної еволюції (1.6.2) / О. О. Демешок / Перший етап модернізації економіки України: досвід та проблеми: Монографія [Текст] / [О. І. Амоша, О. О. Демешок, Л. М. Кузьменко, В. І. Ляшенко та ін. / за наук. ред. В. І. Ляшенко, С. В. Савельєв]; IEП НАН України. - Запоріжжя: Класичний приватний університет, 2014. - 798 с. [С. 132159].

2. Електронний сайт Державної служби статистики України / [ Електронний ресурс]. Режим доступу: http://www.ukrstat.gov.ua/

3. Стан фінансування наукової і науково-технічної діяльності в Україні [Електронний ресурс]: [науково-аналітична записка] / Матеріали слухань у Комітеті Верховної Ради України з питань науки і освіти від 13.03.2013 р. - Київ, ВРУ, 2013. - 615 с. - Режим доступу: http://kno.rada.gov.ua/komosviti/control/uk/publish/article?art_id=56356\&cat_id=54447.

4. Регіональна енергетична політика: основні проблеми і завдання: аналітична доповідь [Електронний ресурс] / Регіональний філіал Національного інституту стратегічних досліджень у м. Дніпропетровську. - Дніпропетровськ, НІСД, 2012. - 50 с. - Режим доступу: http://dp.niss.gov.ua/public/File/docs/ReionPol.pdf

5. Електронний ресурс. - Режим доступу: http://index.minfin.com.ua/index/prod/

6. Рейтингові оцінки за макроекономічними показниками областей України у 2013 році [Електронний $\quad$ ресурс]. http://data.gov.ua/\%D0\%BA\%D0\%B0\%D1\%82\%D0\%B5\%D0\%B3\%D0\%BE\%D1\%80\%D1\%9 $6 \% \mathrm{D} 1 \% 8 \mathrm{~F} / \% \mathrm{D} 0 \% \mathrm{~B} 5 \% \mathrm{D} 0 \% \mathrm{BA} \% \mathrm{D} 0 \% \mathrm{BE} \% \mathrm{D} 0 \% \mathrm{BD} \% \mathrm{D} 0 \% \mathrm{BE} \% \mathrm{D} 0 \% \mathrm{BC} \% \mathrm{D} 1 \% 96 \% \mathrm{D} 0 \% \mathrm{BA} \%$ $\mathrm{D} 0 \% \mathrm{~B} 0$

7. Демешок О. О. Методи та прийоми коригування параметрів економічної безпеки і реструктуризації підприємств (пп. 3.3.) / О. О. Демешок / Формування адаптивної системи забезпечення енергоефективності функціонування суб'єктів господарювання реального сектору економіки України: Монографія [Текст] /[I. А. Ігнатьєва, В. В. Микитенко, I. С. Гращенко, О. О. Демешок, В. В. Хмурова та ін. / за заг. наук. ред. д.е.н., проф., член-кореспондента НАПН 
України І. М. Грищенка та д.е.н., проф. І. А. Ігнатьєвої.]. - Київ: Вид-во «Кафедра», 2012. - 304 c. [C. 181 - 198].

8. Інтегрований огляд інформації щодо позитивних та негативних наслідків вступу України до ЗВТ: аналітична доповідь [Текст]/ Центр комплексних досліджень з питань антимонопольної політики. - Київ: ЦКДПІП, 2014. - 63 с.

9. North, Douglass C. 1981. Structure and Change in Economic History. New York: Norton. 